Article

\title{
Analysis of Anodes of Microbial Fuel Cells When Carbon Brushes Are Preheated at Different Temperatures
}

\author{
Qiao Yang ${ }^{1}{ }^{(D)}$, Shengna Liang ${ }^{1}$, Jia Liu ${ }^{2, *}$, Jiangwei Lv $^{3}$ and Yujie Feng ${ }^{2}$ \\ 1 School of Food and Environment, Dalian University of Technology, No. 2 Dagong Road, Panjin 124221, \\ China; yangqiao@dlut.edu.cn (Q.Y.); lsnlg@mail.dlut.edu.cn (S.L.) \\ 2 State Key Laboratory of Urban Water Resource and Environment, Harbin Institute of Technology, \\ No. 73 Huanghe Road, Harbin 150090, China; yujief@hit.edu.cn \\ 3 School of Pharmacy, Harbin University of Commerce, Harbin 150000, China; pp198259@163.com \\ * Correspondence: jialiu@hit.edu.cn; Tel.: +86-451-8628-7017
}

Received: 21 September 2017; Accepted: 19 October 2017; Published: 25 October 2017

\begin{abstract}
The anode electrode is one of the most important components in all microbial electrochemical technologies (METs). Anode materials pretreatment and modification have been shown to be an effective method of improving anode performance. According to mass loss analysis during carbon fiber heating, five temperatures $\left(300,450,500,600\right.$, and $\left.750{ }^{\circ} \mathrm{C}\right)$ were selected as the pre-heating temperatures of carbon fiber brush anodes. Microbial fuel cell (MFC) reactors built up with these pre-heated carbon brush anodes performed with different power densities and Coulombic efficiencies (CEs). Two kinds of measuring methods for power density were applied, and the numerical values of maximum power densities diverged greatly. Reactors with $450{ }^{\circ} \mathrm{C}$ anodes, using both methods, had the highest power densities, and the highest CEs were found using $500{ }^{\circ} \mathrm{C}$ anode reactors. The surface elements of heat-treated carbon fibers were analyzed using $\mathrm{X}$-ray photoelectron spectra (XPS), and C, O, and $\mathrm{N}$ were the main constituents of the carbon fiber. There were four forms of N1s at the surface of the polyacrylonitrile (PAN)-based carbon fiber, and their concentrations were different at different temperature samples. The microbial community of the anode surface was analyzed, and microbial species on anodes from every sample were similar. The differences in anode performance may be caused by mass loss and by the surface elements. For carbon brush anodes used in MFCs or other BESs, $450-500{ }^{\circ} \mathrm{C}$ preheating was the most suitable temperature range in terms of the power densities and CEs.
\end{abstract}

Keywords: microbial fuel cell; anode; heat treatment; carbon brushes; power generation

\section{Introduction}

A microbial fuel cell (MFC) is a device that uses bacteria to catalyze the conversion of organic matter into electricity [1-5]. Other microbial electrochemical technology (MET) devices have also been developed recently, including microbial electrolysis cells (MECs), microbial desalination cells (MDCs), and microbial reverse-electrodialysis cells (MRCs) [6]. Electrical energy obtained from MFCs and other METs are biological energies, which can be used as renewable energies in the future, when traditional fossil fuels are exhausted [7]. Besides energy recovery, METs have also been used in wastewater treatment, biosensors, and environmental remediation [8-12]. Hydrogen could be bio-produced when a small voltage was applied to the external load, which was described as MECs [13]. When multiple cation exchange membranes and anion exchange membranes were placed between anode and cathode, cation and anion could be explicitly driven in a microbial desalination cell (MDC), and seawater could be desalinated [14-16]. 
All these METs share one common feature: the microbial anode, where electrons are released from bacteria and transmitted onto the surface of anode electrode materials. Besides exoelectrogens, anode materials play an important role as an operational anode in all kinds of METs. Carbon-based materials, including granular graphite [17], carbon paper, carbon cloth [18], and carbon brushes [19,20], are usually chosen for their low cost, electro-conductivity, and biocompatibility. Macroporous graphitic carbon foam and carbon felt have also been used as an anode basic material in high-performance MFCs [21,22]. Among these simple anode materials, excellent performance was obtained using carbon brush anodes, as they had high surface areas and a porous structure [23]. To future improve anode performance, some modifications and treatments were operated on anode materials. Polypyrrole-coated carbon cloth [24], polypyrrole-coated carbon nanotubes [25], carbon nanotube/polyaniline composites [26], and other nanomaterials have been evaluated as an anode material to enhance the bacterial adhesion and increase the power generation. Nanophase and graphene materials are hotspots in multiple research areas and are considered promising anodes of MFCs $[27,28]$. Considering their cost and complex manufacturing processes, ordinary carbon-based materials are still widely used by many researchers. Besides surface area, other factors affect carbon anode performance. Ammonia treatment on carbon brushes has been performed to increase the positive charge of the material surface to enhance power generation to $1970 \mathrm{~mW} / \mathrm{m}^{2}$ [29]. Heat treatment has been used on carbon meshes to improve the performance of mesh anodes as elements changed during the treatments [30]. In the former study, heat treatment, acid treatment, and acid-heat treatment on the brush anode were compared, and the chemical environment of the anode surface was analyzed [31]. Heat treatment has been demonstrated to be a simple and effective method for improving MFC performance, as the concentration ratio of $\mathrm{N} 1 / \mathrm{C} 1$ was increased during heating. Compared with other treatments or modifications, this treatment might be one of the simplest and most effective methods, so many researchers use it for their brush anode pretreatment, according to [31]. However, specific heating temperatures have not yet been tested. To complete the preheating carbon brush anode research, in this study, we chose five different temperatures to preheat the carbon brush anode and compared their performances, and the microbial communities of different anodes were analyzed.

\section{Results and Discussion}

\subsection{Preheating Temperature Selection}

Thermogravimetric analysis was used to assist in the selection of the treatment temperature. During the test, the total mass loss of carbon fibers was $4.3 \%$ when they were heated from room temperature to $1000{ }^{\circ} \mathrm{C}$ in nitrogen gas protection. The remaining mass was declined almost evenly, except for a $1.3 \%$ mass drop between 465 and $485{ }^{\circ} \mathrm{C}$. Therefore, 450 and $500{ }^{\circ} \mathrm{C}$ were selected as the treatment temperatures to verify the effect of the mass drop on the anode performance. 300, 600, and $750{ }^{\circ} \mathrm{C}$ were also selected as treatment temperatures. After the carbon fibers were constantly heated in air for $30 \mathrm{~min}$ at every selected temperature, mass loss was detected. The carbon fiber had lost its original morphology, and only a small amount of ash had been lost after $750{ }^{\circ} \mathrm{C}$ heating for $30 \mathrm{~min}$, so $750{ }^{\circ} \mathrm{C}$ was excluded at first. The carbon fiber of the brush anode after $600{ }^{\circ} \mathrm{C}$ heat was very fragile, and the mass loss of the carbon fibers after heating for $30 \mathrm{~min}$ in a muffle furnace was $21.46 \%$, which is much higher than that of the other fibers, which were $0.86 \%\left(300{ }^{\circ} \mathrm{C}\right), 1.50 \%\left(450{ }^{\circ} \mathrm{C}\right)$, and $2.69 \%$ $\left(500^{\circ} \mathrm{C}\right)$.

\subsection{MFC Reactors Performance}

After all the pretreated anodes were set up in MFC reactors and then inoculated with domestic wastewater, all reactors generated about $580 \mathrm{mV}$ of voltage after several batches except the ones with anode 600 , which obtained less than $20 \mathrm{mV}$ of voltage after $350 \mathrm{~h}$. Since heating at $600{ }^{\circ} \mathrm{C}$ destroyed the original structure of the carbon fiber to a certain extent (mass loss was over $21 \%$ ), it could not support any bacterial enrichment. The following reactor performance test was only related to reactors that 
were set up with the other three kinds of anode $\left(300,450\right.$, and $\left.500{ }^{\circ} \mathrm{C}\right)$. Six hundred degrees Celsius was not a suitable pre-heating temperature for the carbon brush anodes.

Based on the power curves achieved by the one cycle method at different resistances, maximum power densities of $1160 \pm 82\left(300^{\circ} \mathrm{C}\right)$ and $1149 \pm 11\left(500^{\circ} \mathrm{C}\right) \mathrm{mW} / \mathrm{m}^{2}$ were obtained, but the reactor with the $450^{\circ} \mathrm{C}$ anode was able to generate a power density a little higher of $1305 \pm 67 \mathrm{~mW} / \mathrm{m}^{2}$ at a current density of $6.1 \pm 0.2 \mathrm{~A} / \mathrm{m}^{2}$ (Figure 1A). Figure 1B indicates that the cathode potentials were not obviously correlated with the anode and remained consistent with each other, while the anode potentials changed in a manner similar to the manner in which the power densities of the MFCs changed with different preheating anodes. According to the power density curves achieved via linear sweep voltammetry (LSV), the maximum power densities for the reactors with different anodes were $1450\left(300{ }^{\circ} \mathrm{C}\right), 1607\left(450{ }^{\circ} \mathrm{C}\right), 1561\left(500{ }^{\circ} \mathrm{C}\right) \mathrm{mW} / \mathrm{m}^{2}$ (Figure 1C). The highest power density of the $450{ }^{\circ} \mathrm{C}$ reactor using this method was the highest one among all these reactors as well, but the numeric value was $23 \%$ higher than the power obtained by the one cycle method. The increasing numeric value for the $500{ }^{\circ} \mathrm{C}$ reactor using electrochemical methods was highest (increasing from 1149 to $1561 \mathrm{~mW} / \mathrm{m}^{2}$ ). Watson et al. analyzed power density and power overshoot in MFCs with three polarization methods and proved that maximum power densities obtained by LSV were higher than those obtained using the other two resistance methods [32]. The scan rate of $1 \mathrm{mV} / \mathrm{s}$ may be too quick for the reactor to respond to the voltage change, so the power value was unrealistically high, and a maximum power density of $1305 \pm 67 \mathrm{~mW} / \mathrm{m}^{2}$ could be considered. Heat treatment on the carbon anode has been shown to improve MFC performance better than other chemical methods [30,31]; the results obtained in this research confirmed that different heat temperatures have different effects on power generation. Four hundred fifty degrees Celsius is a better treatment temperature than 300 and $500{ }^{\circ} \mathrm{C}$, and temperatures higher than $500^{\circ} \mathrm{C}$ ( such as $600^{\circ} \mathrm{C}$ ) may not be suitable for the anode heat treatment of MFCs.
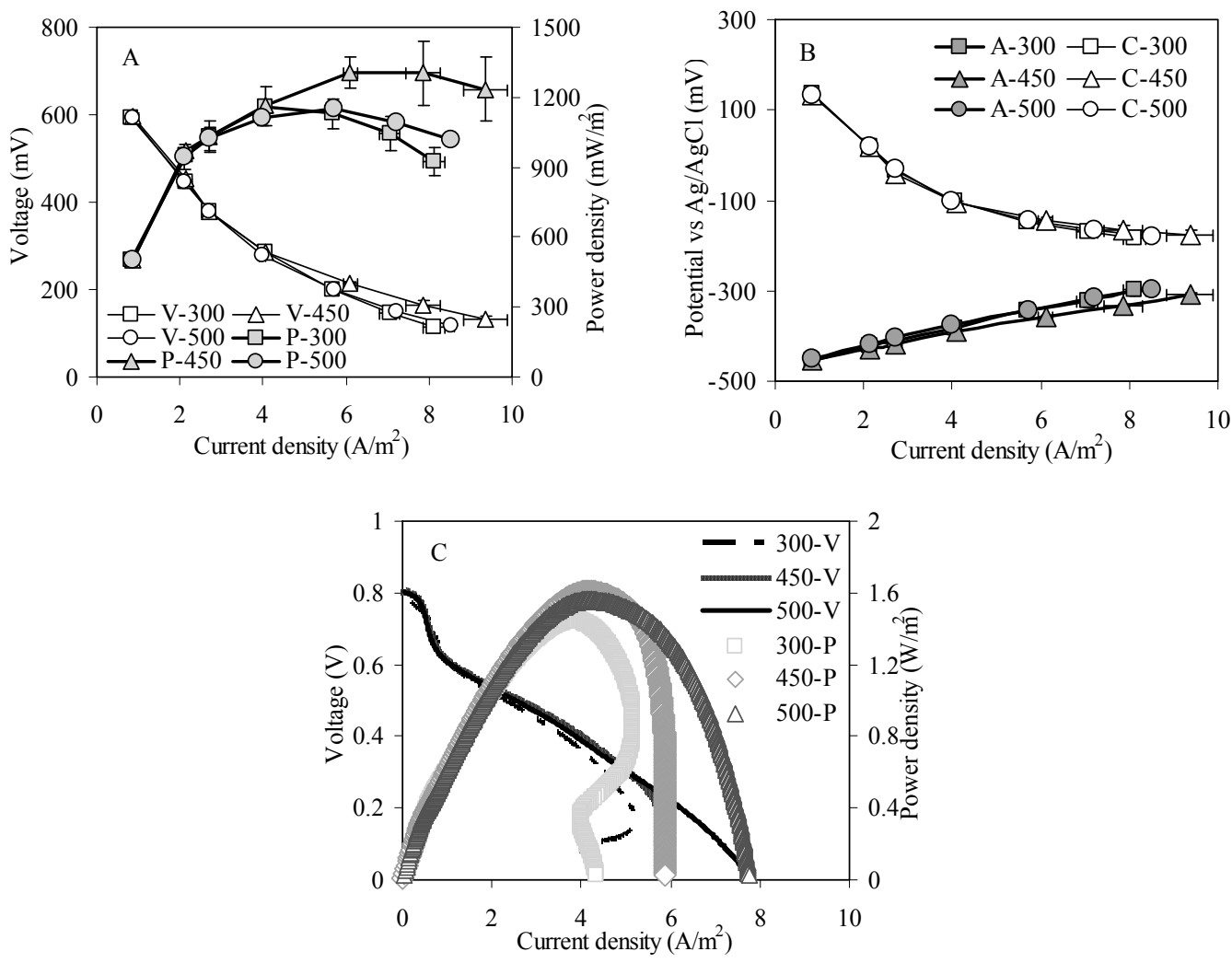

Figure 1. Power density (A) and electrode potential (B) curves for MFCs with different temperature treatment anodes by variable external resistances method and power curves by LSV (C). 
Coulombic efficiencies (CEs) were measured at different external resistances, and there was nearly no difference (22-23\%) between these reactors at low current densities (1000 $\Omega$ external resistance). At a $2.6 \mathrm{~A} / \mathrm{m}^{2}$ current density, CEs increased to $50 \%\left(300{ }^{\circ} \mathrm{C}\right), 53 \%\left(450{ }^{\circ} \mathrm{C}\right)$, and $55 \%\left(500{ }^{\circ} \mathrm{C}\right)$. When they approach a $4 \mathrm{~A} / \mathrm{m}^{2}$ current density (100 $\Omega$ external resistance), the $\mathrm{CE}$ of the $500{ }^{\circ} \mathrm{C}$ reactor increased to $85 \%$, which was higher than both the $450{ }^{\circ} \mathrm{C}$ reactor $(83 \%)$ and the $300{ }^{\circ} \mathrm{C}$ reactor $(72 \%)$. Therefore, a higher heating temperature on the anode could improve the CEs of the MFC reactors at high current density.

\subsection{XPS Analysis on Carbon Fiber Surface}

XPS analysis indicated that $\mathrm{C}, \mathrm{O}$, and $\mathrm{N}$ were the main constituents of the carbon fiber (Figure 2A). Heating at different temperatures changed the element concentration of the carbon fiber. The $600{ }^{\circ} \mathrm{C}$ sample had the highest $\mathrm{N} 1 \mathrm{~s}$ concentrate and the lowest $\mathrm{C} 1 \mathrm{~s}$, while the $300{ }^{\circ} \mathrm{C}$ sample had the opposite result (Figure 2B). Higher heat temperatures caused more carbon loss, and the relative proportions of N1s and O1s improved. The precursor of the carbon fiber used in the research is polyacrylonitrile (PAN) $\left(\mathrm{fCH}_{2} \mathrm{CH}(\mathrm{CN}) \dashv_{\mathrm{n}}\right)$. Most $\mathrm{H}$ and $\mathrm{N}$ elements would be lost during the carbonation process to form the carbon fiber. The element concentration is different based on different carbonation conditions at different carbon fiber plants, including carbonization time and temperature. Therefore, during the following treatment on the carbon fiber, the element concentrations and chemical species were likely to be different because the raw materials were different. Even when the same raw materials from the same plant were used, different results might have been obtained because XPS was only able to detect a sample surface with a thickness of about $10 \mathrm{~nm}$, so storage environment and other factors may have caused different XPS results. Some researchers [30,33] have analyzed the surfaces of other heated carbon fibers and meshes, and, as expected, they had different element concentrations.

Except for the $600{ }^{\circ} \mathrm{C}$ sample, as it failed during reactor start-up, the highest N1s concentration and the highest power density were obtained with $450{ }^{\circ} \mathrm{C}$ treatment. Previous results have also indicated that N1s in the surface of the anode material was related to the power density in MFCs. Although $600{ }^{\circ} \mathrm{C}$ was not a suitable temperature, its N1s peak was much higher than those of other samples and showed a better peak curve shape, which favored the determination of binding energy for every small peak. Referring the binding energy position of N1s, N1s peak separation was finished. Four small peaks constituted the N1s, referred to as N-Q, N-X, N-5, and N-6 [34]. Their content change did not seem to have any obvious regularity because they were easily affected by other factors as stated above (Figure 2D). Even though we tried to identify the relation between N-Q, N-X, N-5, or $\mathrm{N}-6$ concentration and anode performance, no authentic conclusion could be made based on these XPS analysis.

After reactor performances were tested, the anodes were ultrasonically cleaned multiple times via dipping in deionized water, and XPS analysis was then applied on carbon brush fibers again to determine the anode surface. Element concentrations for all samples were similar: C1s concentrations were $72 \sim 74 \%$, O1s concentrations were from $19 \%$ to $21 \%$, N1s concentrations were between $6 \%$ and $8 \%$, and there was about $1 \%$ S1s (Figure 2C). Bacteria enriched the anode surface when the MFC reactor was operated. XPS was only able to analyze material surfaces with a $10 \mathrm{~nm}$ thickness. Considering the changes in elements before and after brush anodes were used in the reactors, element concentrations of the used anode samples detected by XPS should partially constitute by anode bacteria. 

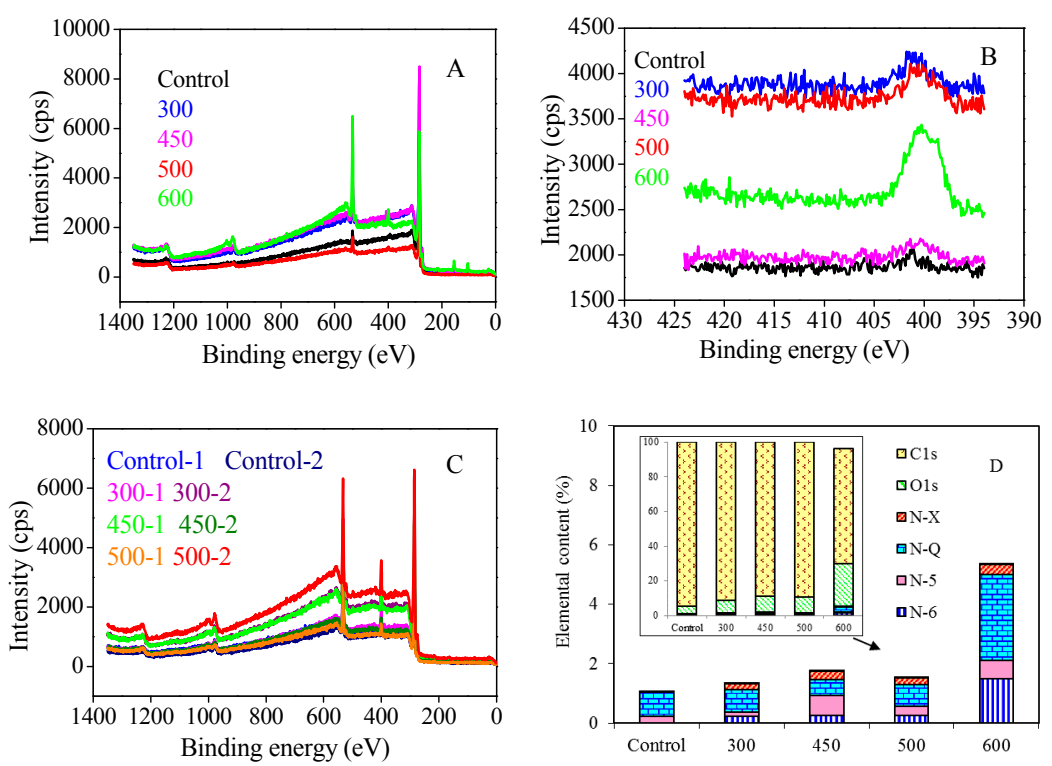

Figure 2. XPS analysis: (A) Wide spectrum of carbon fiber heated at different temperatures. (B) High-resolution N1s spectra of carbon fibers via different heat treatments. (C) Wide spectrum of used carbon fiber. (D) Peak separation results of high-resolution N1s spectra for carbon fiber heated at different temperatures.

\subsection{The Anode Microbial Community}

After the reactors were disassembled, the biofilm on the anode surface was analyzed via Polymerase Chain Reaction-Denaturing Gradient Gel Electrophoresis (PCR-DGGE) techniques. Based on a comparative analysis of the $16 \mathrm{~S}$ rDNA gene sequences, 11 groups were identified in the MFC microbial community (Figure 3). All the anode samples, which represented three different temperatures, had similar band positions, which meant that bacteria enriched on anodes might not make any appreciable difference. Different preheating temperatures did no appear to significantly affect the anode microbial community in these systems.

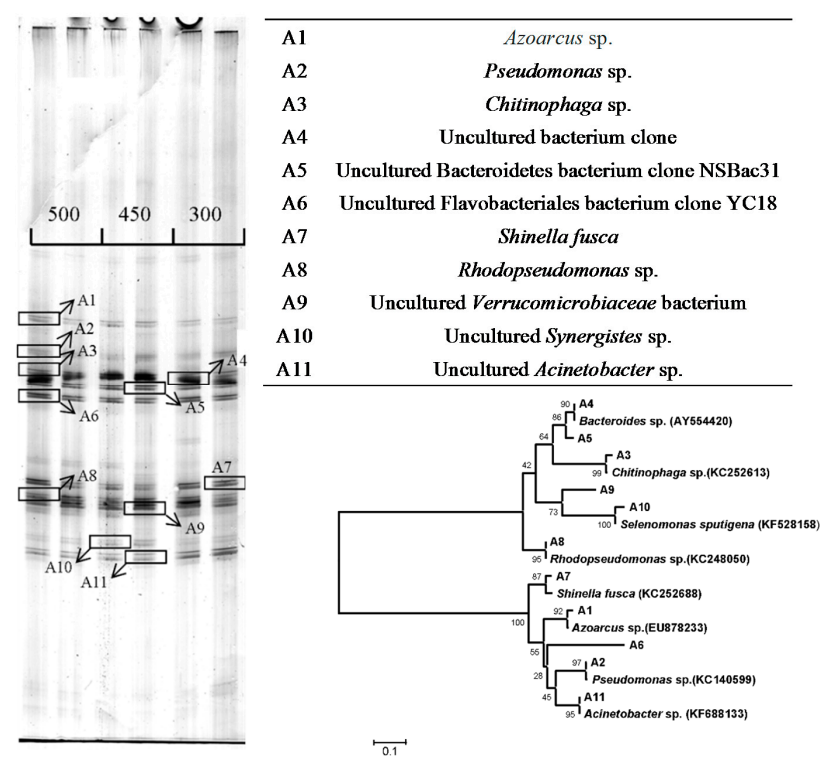

Figure 3. Characterization of cloned 16s rDNA gene fragments of different anodes and phylogenetic trees showing the relationships between the anode community and related species. 
Anode bands were sequenced and are listed in Figure 3. The A1 sequence type represented in the clone library showed $99 \%$ identity to Azoarcus sp., which can use nitrate as an electron acceptor to degrade organic compounds [35]. In some MET-related studies, Azoarcus sp. were found in chocolate wastewater-based MFC anodes [36]. Alcohol-powered MFCs were the second dominant community members [37]. The A2 sequence type was $99 \%$ similar to uncultured Pseudomonas sp., which have been proven to self-produce phenazine-based mediators in the anodes of MFCs to improve electricity generation [38]. Furthermore, Pham et al. demonstrated that metabolites produced by Pseudomonas sp. enable Gram-positive bacteria to achieve extracellular electron transfer in acetate-fed MFCs [39]. The A5 sequence type was 99\% similar to an uncultured Bacteroidetes bacterium, and Bacteroidetes were the dominant phyla in the MFCs with granular graphite, granular semicoke, and carbon felt cubes as anodic materials, but not in the granular activated carbon-packed MFCs [40]. In a wheat straw hydrolysate-fed two-chambered MFC, the bacteria in the biofilm were consortia with sequences similar to those of Bacteroidetes ( $40 \%$ of sequences) [41]. A8 with sequences $99 \%$ was similar to Rhodopseudomonas sp., which are capable of high power production. Rhodopseudomonas palustris DX-1 produced electricity of $2720 \pm 60 \mathrm{~mW} / \mathrm{m}^{2}$, which was higher than that of mixed cultures in the same device [42]. Therefore, many microorganisms attached to different anode biofilms were capable of power production or self-produced mediators, but the significant differences in the anode microbial community cannot be found based on this research. The performance difference of these reactors were not obviously correlated with the anode bacteria.

\section{Materials and Methods}

\subsection{MFC Construction with Heat-Treated Anodes}

Air cathodes were made of wet proof carbon clothes with $0.5 \mathrm{mg} / \mathrm{m}^{2} \mathrm{Pt}$ catalyst on the water side and four diffusion layers on the air side [18]. All the carbon brush anodes were made from carbon fibers and titanium wires as previously described [23]. The size of every carbon brush anode was $\phi 25 \mathrm{~mm} \times 25 \mathrm{~mm}$. After these anodes were soaked in acetone overnight and acid-treated for $15 \mathrm{~min}$ as previously described [31], they were heat-treated in a muffle furnace for $30 \mathrm{~min}$ at $300{ }^{\circ} \mathrm{C}$, $450{ }^{\circ} \mathrm{C}, 500^{\circ} \mathrm{C} 600^{\circ} \mathrm{C}$, or $750{ }^{\circ} \mathrm{C}$. The single-chamber MFCs used in this research was a cubic reactor ( $40 \mathrm{~mm} \times 40 \mathrm{~mm} \times 40 \mathrm{~mm}$ ) with a cylinder hole (40 mm length, $30 \mathrm{~mm}$ diameter, $28 \mathrm{~mL}$ volume). The air cathode was placed on one side to cover the hole. The other side was sealed with a plastic end with an anode placed inside the sealed chamber in a homocentric manner. The anode heat-treated at $300{ }^{\circ} \mathrm{C}$ was named Anode 300, and other anodes were similarly named. Each kind of anode was placed in duplicate reactors.

\subsection{MFC Operation}

All the reactors were inoculated using domestic sewage obtained from an urban wastewater system. The feeding medium was composed of sodium acetate $(1 \mathrm{~g} / \mathrm{L})$, a phosphate buffer solution $(50 \mathrm{mM} / \mathrm{L}, \mathrm{pH}=7)$, minerals $(12.5 \mathrm{~mL} / \mathrm{L})$, and vitamins $(5 \mathrm{~mL} / \mathrm{L})$. All reactors were operated in batch mode in a room at a constant temperature of $30^{\circ} \mathrm{C}$. The power density curve was obtained by two methods after feeding with fresh medium: one measuring method was the "one cycle method" [43] where the external resistance was changed every $30 \mathrm{~min}$ in one cycle, and the other method was via LSV with an electrochemical station with a scan rate of $1 \mathrm{mV} / \mathrm{s}$. CE was calculated according to methods mentioned previously [44].

\subsection{Analysis Methods}

Thermogravimetric analysis was operated using an STA 449 (NETZSCH, Hannover, Germany). Carbon fibers were heated from room temperature to $1000^{\circ} \mathrm{C}$ at a rate of $10^{\circ} \mathrm{C} / \mathrm{min}$, and the mass loss and temperature were recorded simultaneously. Carbon fibers were tested by X-ray photoelectron spectra (XPS; PHI 5700 ESCA System, Physical Electronics, Chanhassen, MN, USA) to identify the 
surface elements. High-resolution XPS spectra were used to analyze single elements. Peak fitting was operated using Physical Electronics PC-ACCESS ESCA V7.2C. C-C Peaks were shifted to $285 \mathrm{eV}$, and charge correction for other elements followed. A Gaussian-Lorentz model was used in peak fitting using binding energies noted in the literature. Bacteria were taken from the anode by removing a piece of the carbon fibers. Total DNA was extracted using a Power Soil DNA Isolation Kit (MOBIO Laboratories, Inc., Carlsbad, CA, USA) according to the instructions of the manufacturer. Amplification of 16S rDNA gene fragments were performed using the primer pairs of GC-519F (5'-CGCCCGCCGCGCGCGGCGGGCGGGGCGGGGGCACGGGGGGCAGCAGCCGCGGTAATAC-3') and 926R ( $5^{\prime}$-CCGTCAATTCATTTGAGTTT-3'). Denaturing gradient gel electrophoresis (DGGE) was performed using a Bio-Rad Dcode Universal Mutation Detection System (Version 9080, Bio-Rad, Hercules, CA, USA). 16S rDNA sequence was analyzed at the National Center for Biotechnology Information (http:/ /blast.ncbi.nlm.nih.gov/Blast.cgi). The tree was constructed using the neighbor-joining method. Bootstrap values at nodes were calculated using 1000 replicates.

\section{Conclusions}

Five temperatures were selected for carbon brush preheat treatment. Because of the mass loss of the carbon fiber, a temperature higher than $600{ }^{\circ} \mathrm{C}$ was not suitable for anode treatment. Heated MFCs with $450{ }^{\circ} \mathrm{C}$ pretreated anodes, using both variable external resistances and LSV methods, had the highest power density, but the specific values were different. The highest $C E$ was found in reactors set up with the $500{ }^{\circ} \mathrm{C}$ anode. There were four kinds of N1s at the surface of carbon fiber based on XPS analysis, and their concentrations changed during the heating process. Analysis of the anode microbial community using PCR-DGGE techniques indicated that the Azoarcus sp., Pseudomonas sp., and Rhodopseudomonas sp. were significant members of the anode bacteria. The communities of the anode microbial species were similar for all the reactors, which were not affected by preheat treatment. Heat pretreatment on the carbon brush anodes at different temperatures affected the N1s concentration of the carbon fiber and the MFC reactor performance, but did not affect the anode microbial community $450-500{ }^{\circ} \mathrm{C}$ preheating is recommended considering both the maximum power density and the CE.

Acknowledgments: This work was supported by the Open Project of State Key Laboratory of Urban Water Resource and Environment, Harbin Institute of Technology (No. HC201704), the National Natural Science Foundation of China (51708087), the General Project of Liaoning Provincial Department of Education (L2015119), and the Fundamental Research Funds for the Central Universities (DUT16RC(4)82).

Author Contributions: Yujie Feng and Jia Liu conceived and designed the experiments; Qiao Yang and Shengna Liang performed the experiments; Jiangwei Lv contributed analysis tools; Qiao Yang wrote the paper.

Conflicts of Interest: The authors declare no conflict of interest.

\section{References}

1. Allen, R.M.; Bennetto, H.P. Microbial fuel-cells: Electricity production from carbohydrates. Appl. Biochem. Biotechnol. 1993, 39, 27-40. [CrossRef]

2. Wingard, L.B.; Shaw, C.H.; Castner, J.F. Bioelectrochemical fuel cells. Enzyme Microb. Technol. 1982, 4, 137-142. [CrossRef]

3. Kim, H.J.; Park, H.S.; Hyun, M.S.; Chang, I.S.; Kim, M.; Kim, B.H. A mediator-less microbial fuel cell using a metal reducing bacterium, Shewanella putrefaciense. Enzyme Microb. Technol. 2002, 30, 145-152. [CrossRef]

4. Bond, D.R.; Lovley, D.R. Electricity production by Geobacter sulfurreducens attached to electrodes. Appl. Environ. Microbiol. 2003, 69, 1548-1555. [CrossRef] [PubMed]

5. Rabaey, K.; Verstraete, W. Microbial fuel cells: Novel biotechnology for energy generation. Trends Biotechnol. 2005, 23, 291-298. [CrossRef] [PubMed]

6. Logan, B.E.; Wallack, M.J.; Kim, K.-Y.; He, W.; Feng, Y.; Saikaly, P.E. Assessment of Microbial Fuel Cell Configurations and Power Densities. Environ. Sci. Technol. Lett. 2015, 2, 206-214. [CrossRef]

7. Cusick, R.D.; Kim, Y.; Logan, B.E. Energy Capture from Thermolytic Solutions in Microbial Reverse-Electrodialysis Cells. Science 2012, 335, 1474-1477. [CrossRef] [PubMed] 
8. Liu, H.; Ramnarayanan, R.; Logan, B.E. Production of electricity during wastewater treatment using a single chamber microbial fuel cell. Environ. Sci. Technol. 2004, 38, 2281-2285. [CrossRef] [PubMed]

9. Min, B.; Logan, B.E. Continuous electricity generation from domestic wastewater and organic substrates in a flat plate microbial fuel cell. Environ. Sci. Technol. 2004, 38, 5809-5814. [CrossRef] [PubMed]

10. Chang, I.S.; Jang, J.K.; Gil, G.C.; Kim, M.; Kim, H.J.; Cho, B.W.; Kim, B.H. Continuous determination of biochemical oxygen demand using microbial fuel cell type biosensor. Biosens. Bioelectron. 2004, 19, 607-613. [CrossRef]

11. Kim, B.H.; Chang, I.S.; Gil, G.C.; Park, H.S.; Kim, H.J. Novel BOD (biological oxygen demand) sensor using mediator-less microbial fuel cell. Biotechnol. Lett. 2003, 25, 541-545. [CrossRef] [PubMed]

12. Wang, H.; Luo, H.; Fallgren, P.H.; Jin, S.; Ren, Z.J. Bioelectrochemical system platform for sustainable environmental remediation and energy generation. Biotechnol. Adv. 2015, 33, 317-334. [CrossRef] [PubMed]

13. Call, D.; Logan, B.E. Hydrogen production in a single chamber microbial electrolysis cell lacking a membrane. Environ. Sci. Technol. 2008, 42, 3401-3406. [CrossRef] [PubMed]

14. Cao, X.X.; Huang, X.; Liang, P.; Xiao, K.; Zhou, Y.J.; Zhang, X.Y.; Logan, B.E. A New Method for Water Desalination Using Microbial Desalination Cells. Environ. Sci. Technol. 2009, 43, 7148-7152. [CrossRef] [PubMed]

15. Chen, X.; Xia, X.; Liang, P.; Cao, X.X.; Sun, H.T.; Huang, X. Stacked Microbial Desalination Cells to Enhance Water Desalination Efficiency. Environ. Sci. Technol. 2011, 45, 2465-2470. [CrossRef] [PubMed]

16. Zuo, K.; Wang, Z.; Chen, X.; Zhang, X.; Zuo, J.; Liang, P.; Huang, X. Self-Driven Desalination and Advanced Treatment of Wastewater in a Modularized Filtration Air Cathode Microbial Desalination Cell. Environ. Sci. Technol. 2016, 50, 7254-7262. [CrossRef] [PubMed]

17. Rabaey, K.; Clauwaert, P.; Aelterman, P.; Verstraete, W. Tubular microbial fuel cells for efficient electricity generation. Environ. Sci. Technol. 2005, 39, 8077-8082. [CrossRef] [PubMed]

18. Cheng, S.; Liu, H.; Logan, B.E. Increased performance of single-chamber microbial fuel cells using an improved cathode structure. Electrochem. Commun. 2006, 8, 489-494. [CrossRef]

19. Yang, Q.; Wu, Z.; Liu, L.; Zhang, F.; Liang, S. Treatment of Oil Wastewater and Electricity Generation by Integrating Constructed Wetland with Microbial Fuel Cell. Materials 2016, 9, 885. [CrossRef] [PubMed]

20. Wang, H.; Yi, S.; Cao, X.; Fang, Z.; Li, X. Reductive dechlorination of hexachlorobenzene subjected to several conditions in a bioelectrochemical system. Ecotoxicol. Environ. Saf. 2017, 139, 172-178. [CrossRef] [PubMed]

21. Habibul, N.; Hu, Y.; Sheng, G.-P. Microbial fuel cell driving electrokinetic remediation of toxic metal contaminated soils. J. Hazard. Mater. 2016, 318, 9-14. [CrossRef] [PubMed]

22. Jiang, H.; Yang, L.; Deng, W.; Tan, Y.; Xie, Q. Macroporous graphitic carbon foam decorated with polydopamine as a high-performance anode for microbial fuel cell. J. Power Sources 2017, 363, 27-33. [CrossRef]

23. Logan, B.; Cheng, S.; Watson, V.; Estadt, G. Graphite fiber brush anodes for increased power production in air-cathode microbial fuel cells. Environ. Sci. Technol. 2007, 41, 3341-3346. [CrossRef] [PubMed]

24. Jiang, D.Q.; Li, B.K. Novel electrode materials to enhance the bacterial adhesion and increase the power generation in microbial fuel cells (MFCs). Water Sci. Technol. 2009, 59, 557-563. [CrossRef] [PubMed]

25. Zou, Y.J.; Xiang, C.L.; Yang, L.N.; Sun, L.X.; Xu, F.; Cao, Z. A mediatorless microbial fuel cell using polypyrrole coated carbon nanotubes composite as anode material. Int. J. Hydrogen Energy 2008, 33, 4856-4862. [CrossRef]

26. Qiao, Y.; Li, C.M.; Bao, S.J.; Bao, Q.L. Carbon nanotube/polyaniline composite as anode material for microbial fuel cells. J. Power Sources 2007, 170, 79-84. [CrossRef]

27. Wang, H.; Wang, G.; Ling, Y.; Qian, F.; Song, Y.; Lu, X.; Chen, S.; Tong, Y.; Li, Y. High power density microbial fuel cell with flexible 3D graphene-nickel foam as anode. Nanoscale 2013, 5, 10283-10290. [CrossRef] [PubMed]

28. Fan, Y.; Xu, S.; Schaller, R.; Jiao, J.; Chaplen, F.; Liu, H. Nanoparticle decorated anodes for enhanced current generation in microbial electrochemical cells. Biosens. Bioelectron. 2011, 26, 1908-1912. [CrossRef] [PubMed]

29. Cheng, S.A.; Logan, B.E. Ammonia treatment of carbon cloth anodes to enhance power generation of microbial fuel cells. Electrochem. Commun. 2007, 9, 492-496. [CrossRef]

30. Wang, X.; Cheng, S.A.; Feng, Y.J.; Merrill, M.D.; Saito, T.; Logan, B.E. Use of Carbon Mesh Anodes and the Effect of Different Pretreatment Methods on Power Production in Microbial Fuel Cells. Environ. Sci. Technol. 2009, 43, 6870-6874. [CrossRef] [PubMed] 
31. Feng, Y.J.; Yang, Q.; Wang, X.; Logan, B.E. Treatment of carbon fiber brush anodes for improving power generation in air-cathode microbial fuel cells. J. Power Sources 2010, 195, 1841-1844. [CrossRef]

32. Watson, V.J.; Logan, B.E. Analysis of polarization methods for elimination of power overshoot in microbial fuel cells. Electrochem. Commun. 2011, 13, 54-56. [CrossRef]

33. Saito, T.; Mehanna, M.; Wang, X.; Cusick, R.D.; Feng, Y.J.; Hickner, M.A.; Logan, B.E. Effect of nitrogen addition on the performance of microbial fuel cell anodes. Bioresour. Technol. 2011, 102, 395-398. [CrossRef] [PubMed]

34. Pels, J.R.; Kapteijn, F.; Moulijn, J.A.; Zhu, Q.; Thomas, K.M. Evolution of nitrogen functionalities in carbonaceous materials during pyrolysis. Carbon 1995, 33, 1641-1653. [CrossRef]

35. Lin, Z.-Q.; Yuan, S.-J.; Li, W.-W.; Chen, J.-J.; Sheng, G.-P.; Yu, H.-Q. Denitrification in an integrated bioelectro-photocatalytic system. Water Res. 2017, 109, 88-93. [CrossRef] [PubMed]

36. Pan, Y.; Wang, Y.; Zhou, A.; Wang, A.; Wu, Z.; Lv, L.; Li, X.; Zhang, K.; Zhu, T. Removal of azo dye in an up-flow membrane-less bioelectrochemical system integrated with bio-contact oxidation reactor. Chem. Eng. J. 2017, 326, 454-461. [CrossRef]

37. Chen, H.; Gao, X.; Wang, C.; Shao, J.; Xu, X.; Zhu, L. Efficient 2,4-dichloronitrobenzene removal in the coupled BES-UASB reactor: Effect of external voltage mode. Bioresour. Technol. 2017, 241, 879-886. [CrossRef] [PubMed]

38. Zhang, E.; Wang, F.; Zhai, W.; Scott, K.; Wang, X.; Diao, G. Efficient removal of nitrobenzene and concomitant electricity production by single-chamber microbial fuel cells with activated carbon air-cathode. Bioresour. Technol. 2017, 229, 111-118. [CrossRef] [PubMed]

39. Qiu, R.; Zhang, B.; Li, J.; Lv, Q.; Wang, S.; Gu, Q. Enhanced vanadium (V) reduction and bioelectricity generation in microbial fuel cells with biocathode. J. Power Sources 2017, 359, 379-383. [CrossRef]

40. Zhang, Q.; Zhang, Y.; Li, D. Cometabolic degradation of chloramphenicol via a meta-cleavage pathway in a microbial fuel cell and its microbial community. Bioresour. Technol. 2017, 229, 104-110. [CrossRef] [PubMed]

41. Ding, Y.; Sun, W.; Cao, L.; Yang, J. A spontaneous catalytic membrane reactor to dechlorinate 2,4,6-TCP as an organic pollutant in wastewater and to reclaim electricity simultaneously. Chem. Eng. J. 2016, 285, 573-580. [CrossRef]

42. Gao, C.; Liu, L.; Yang, F. Development of a novel proton exchange membrane-free integrated MFC system with electric membrane bioreactor and air contact oxidation bed for efficient and energy-saving wastewater treatment. Bioresour. Technol. 2017, 238, 472-483. [CrossRef] [PubMed]

43. Logan, B.E.; Hamelers, B.; Rozendal, R.A.; Schrorder, U.; Keller, J.; Freguia, S.; Aelterman, P.; Verstraete, W.; Rabaey, K. Microbial fuel cells: Methodology and technology. Environ. Sci. Technol. 2006, 40, 5181-5192. [CrossRef] [PubMed]

44. Yang, Q.; Wang, X.; Feng, Y.; Lee, H.; Liu, J.; Shi, X.; Qu, Y.; Ren, N. Electricity generation using eight amino acids by air-cathode microbial fuel cells. Fuel 2012, 102, 478-482. [CrossRef] 